\title{
Biotransformation of Chalcones by the Endophytic Fungus Aspergillus flavus Isolated from Paspalum maritimum Trin.
}

\author{
Marivaldo J. C. Corrêa, ${ }^{a}$ Fátima M. Nunes, ${ }^{a}$ Heriberto R. Bitencourt, ${ }^{a}$ Fábio C. Borges, ${ }^{a}$ \\ Giselle M. S. P. Guilhon, ${ }^{a}$ Mara S. P. Arruda, ${ }^{a}$ Andrey M. R. Marinho, ${ }^{a}$ Alberdan S. Santos, ${ }^{a}$ \\ Cláudio N. Alves, ${ }^{a}$ Davi S. B. Brasil ${ }^{b}$ and Lourivaldo S. Santos ${ }^{*, a}$ \\ aPrograma de Pós-Graduação em Química, Instituto de Ciências Exatas e Naturais and \\ ${ }^{b}$ Faculdade de Engenharia Química, Instituto de Tecnologia, Universidade Federal do Pará, \\ Campus Universitário do Guamá, 66075-900 Belém-PA, Brazil
}

O fungo Aspergillus flavus isolado como endofítico da planta Paspalum maritimum Trin. foi avaliado quanto ao seu potencial de aplicação em reações de biotransformações. Os compostos chalcona (1), 3,4,5-trimetoxichalcona (2) e 2,3,4,4'-tetrametoxichalcona (3) foram biotransformados, respectivamente, na diidrochalcona (4), 3,4,5-trimetoxidiidrochalcona (5) e 2,3,4,4'-tetrametoxidiidrochalcona (6). As estruturas destes compostos foram determinadas por análises de RMN uni e bidimensionais e por espectrometria de massas. As diidrochalconas 5 e 6 são substâncias inéditas.

The fungus Aspergillus flavus isolated as endophytic of the plant Paspalum maritimum Trin. was evaluated for its potential application in biotransformation reactions. The compounds chalcone (1), 3,4,5-trimethoxychalcone (2) and 2,3,4,4'-tetramethoxychalcone (3) were biotransformed, respectively, in dihydrochalcone (4), 3,4,5-trimethoxydihydrochalcone (5) and 2,3,4,4'-tetramethoxydihydrochalcone (6). The structures were elucidated by spectroscopic methods including 1D and 2D NMR techniques, and MS analysis. The dihydrochalcones 5 and $\mathbf{6}$ are new compounds.

Keywords: biotransformations, Aspergillus flavus, Paspalum maritimum, chalcones, dihydrochalcones

\section{Introduction}

Chemical reactions performed by microorganisms have been used as an alternative to obtain products of chemical and biological interest. Taking into account the modern concepts and requirements for a safer and environmentally friendly chemistry, the use of reactions promoted by microorganisms tends to increase in the near future. ${ }^{1-3}$ Such reactions, usually known as biotransformation, have certain advantages over the conventional reactions. Biotransformation is usually performed in aqueous systems and at neutral $\mathrm{pH}$, preventing the common use of dangerous solvents in conventional synthesis. ${ }^{4-9}$ In addition, microorganisms are capable of performing a wide variety of reactions, including some almost inaccessible by chemical means. ${ }^{10-13}$

*e-mail: 1ss@ufpa.br
Chalcones are precursors of the flavonoids and are defined as $\alpha, \beta$-unsaturated ketones in which both the carbonyl and the olefinic fragment are linked to an aromatic ring. They possess a large spectrum of action, such as antiviral activity, ${ }^{14}$ inhibition of NS3 protease of dengue virus, ${ }^{15}$ activity against herpes simplex virus, ${ }^{16}$ HIV-1 replication inhibition in lymphocytes-H9 in mice, ${ }^{17}$ allelopathic activity, ${ }^{18}$ anti-inflammatory and antibacterial properties. ${ }^{19}$ These activities have been raising the interest in synthesizing and characterizing different chalcones, in order to obtain the corresponding dihydrochalcones to correlate structure versus biological activity.

Biotransformation of bioactive natural and synthetic compounds by many microorganisms including species of Aspergillus have been examined and investigated. ${ }^{20,21}$ Regioselective $O$-demethylation of flavones into their 4'-O-demethylated metabolites was performed using an A. niger strain. ${ }^{22}$ Biotransformation of flavanones by one wild 
strain of $A$. niger $K B$ and three UV mutants of $A$. niger resulted in the reduction of carbonyl group and dehydrogenation at C-2 and C-3 positions; reduction of carbonyl group and hydroxylation at C-7; and dehydrogenation at C-2 and C-3 and hydroxylation at $\mathrm{C}-3$ producing flavonol. ${ }^{23}$ In the high molecular weight fraction of the culture extract of Aspergillus oryzae, genistein was transformed into shoyuflavone B in the presence of ( \pm )-transepoxysuccinic acid. ${ }^{24}$ Epigallocatechin gallate (EGCG) has been reported to be converted into epigallocatechin (EGC) by a hydrolase from Aspergillus oryzae and the yield of EGC could reach at least $70 \% .^{25}$ Biotransformation of the flavanone by means of Aspergillus niger $M B$ culture led to formation of three products: 6-hydroxyflavanone, 2',5'-dihydroxydihydrochalcone and 2 '-hydroxydihydrochalcone. Their yields were 18\%, $6 \%$ and $7.5 \%$ after 9 days, respectively. ${ }^{26}$

Due to the potential ability of Aspergillus to promote biotransformation reactions, we decided to study biotransformation reactions of chalcone (1), 3,4,5-trimethoxychalcone (2) and 2,3,4,4'-tetramethoxychalcone (3), using the endophytic fungus Aspergillus flavus isolated from the plant Paspalum maritimum.

\section{Results and Discussion}

The chalcones $\mathbf{1}(68.5 \%$ yield $),{ }^{27} \mathbf{2}(75.0 \% \text { yield })^{28}$ and $3(60.0 \% \text { yield })^{29}$ were synthesized using methodology described in the literature ${ }^{18}$ and their structures were determined by the analysis of 1D- and 2D-NMR, mass spectral information and comparison with reported physical and spectroscopic data. These chalcones were bioreduced by Aspergillus flavus producing the dihydrochalcones 4 ( $74.5 \%$ yield), 5 (36.3\% yield) and 6 (15.6\% yield), respectively, after 10 days of reaction (Figure 1). The known dihydrochalcone (4) was identified by comparison of the spectroscopic data with those published in literature..$^{30}$ The dihydrochalcones 5 and $\mathbf{6}$ are new compounds.

The bioreduction reaction of the chalcones was regioselective, showing only alteration in carboncarbon double bond of the olefin, with no reaction at the carbonyl double bond. Several reactions of chalcones are reported, however, none of them showed regioselectivity for the double bond C-2 and C-3. Among the reactions of biotransformation reported directly on chalcones, Aspergillus alliaceus cyclized the chalcone 2'-hydroxy2,3-dimethoxychalcone to three flavanones and to $O$-demethylated ( $6.5 \%$ yield) and hydroxylated ( $7.2 \%$ yield) chalcones. ${ }^{31}$ The unsubstituted chalcone was converted to 2"-hydroxychalcone and 2",3"-dihydroxychalcone in $25 \%$ and $59 \%$ yields, respectively, by Escherichia coli. ${ }^{32}$ Microbial transformation of chalcone xanthohumol, using the culture broth of Pichia membranifaciens afforded three metabolites, one isomeric prenylflavanone in $3.3 \%$ yield, and two modified prenylchalcones in 0.55 and $0.58 \%$ yield. ${ }^{33}$ The yields obtained in the biotransformation reactions of chalcones to dihydrochalcones in this work are higher (15.6-75.5\% yield) than those reported in the literature, although no reaction can be directly compared, because none of them performed this type of bioreduction (direct formation of dihydrochalcones from chalcone).

The biotransformation products (dihydrochalcones $\mathbf{4}$, 5 and 6 ) were characterized mainly by the presence of two triplets in the ${ }^{1} \mathrm{H}$ NMR spectra that indicate the reduction of the double bond of the conjugated olefinic system. In the ${ }^{13} \mathrm{C}$ NMR spectrum, the chemical shift of the carbonyl carbon increased about $10 \mathrm{ppm}$ due to the loss of conjugation.

Compound 5 was identified as 3,4,5-trimethoxydihydrochalcone. The analysis of the LR-MS spectrum showed that compound 5 has a molecular ion peak at $\mathrm{m} / \mathrm{z}$ $300(64 \%)$ and fragments at $m / z, 195$ (100\%), 181 (36\%), $165(42 \%)$ and $77(36 \%)$, suggesting a molecular formula

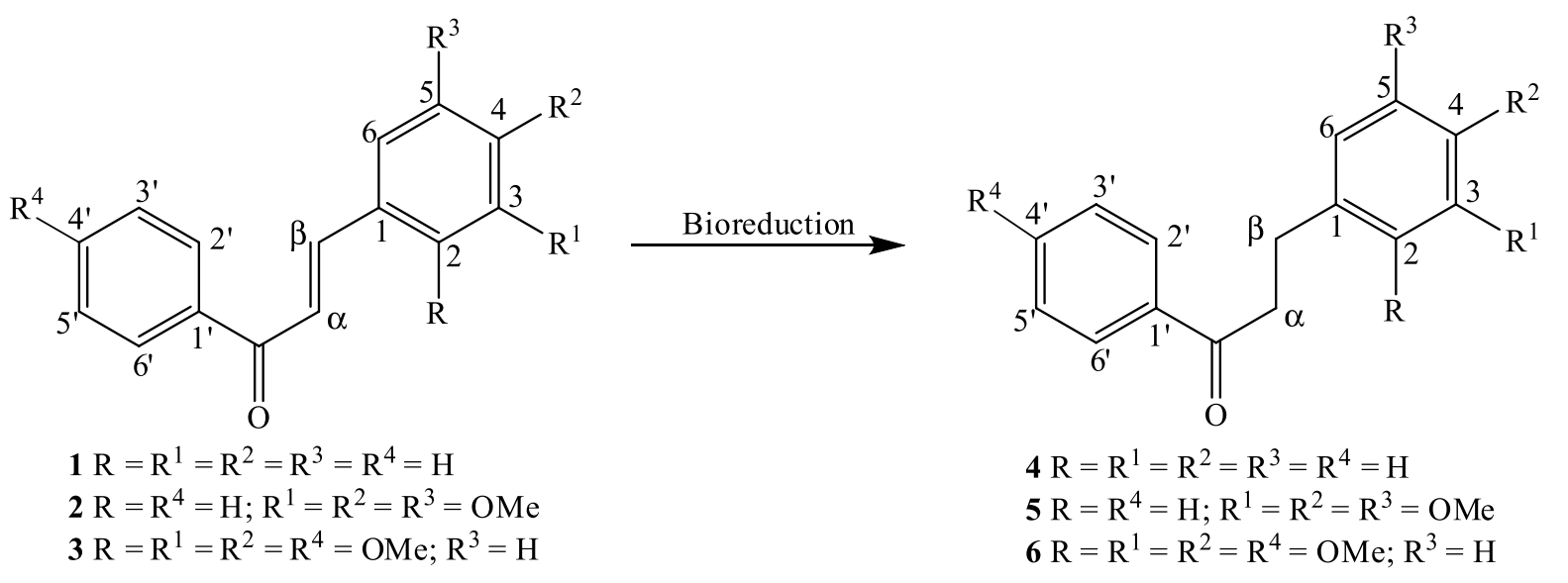

Figure 1. Bioreduction of the chalcones 1, $\mathbf{2}$ and $\mathbf{3}$ by Aspergillus flavus. 
$\mathrm{C}_{18} \mathrm{H}_{20} \mathrm{O}_{4}$ (9 degrees of insaturation). This molecular formula was confirmed on the basis of HRESIMS $[\mathrm{m} / \mathrm{z}$ $\left.323.1270(\mathrm{M}+\mathrm{Na})^{+} ; \Delta-1.1 \mathrm{mmu}\right]$ analysis and NMR data (Table 1). The ${ }^{1} \mathrm{H}$ NMR spectrum of $\mathbf{5}$ (Table 1) showed signals due to the benzylic methylene protons $\mathrm{H} \beta$ at $\delta_{\mathrm{H}}$ $3.01(2 \mathrm{H}, t, J 7.5 \mathrm{~Hz})$ and to the $\alpha$-carbonyl protons $\mathrm{H} \alpha$ at $\delta_{\mathrm{H}} 3.29(2 \mathrm{H}, t, J 7.5 \mathrm{~Hz})$. The coupling of the protons $\mathrm{H} \alpha$ and $\mathrm{H} \beta$ was confirmed by analysis of ${ }^{1} \mathrm{H} \times{ }^{1} \mathrm{H}-\mathrm{COSY}$ spectrum. HETCOR spectrum $\left({ }^{1} J_{\mathrm{CH}}\right)$ showed correlations of the signals of the protons at $\delta_{\mathrm{H}} 3.29(\mathrm{H} \alpha)$ and $3.01(\mathrm{H} \beta)$ with signals at $\delta_{\mathrm{C}} 40.6(\mathrm{C} \alpha)$ and $30.6(\mathrm{C} \beta)$, respectively. The triplet at $\delta_{\mathrm{H}} 3.01$, assigned to the signal of hydrogen $\mathrm{H} \beta$, showed a correlation in the HMBC spectrum with the signals at $\delta_{\mathrm{C}} 137.1(\mathrm{C} 1)$ and at $\delta_{\mathrm{C}} 105.4(\mathrm{C} 2 / \mathrm{C} 6)$. The singlet at $\delta_{\mathrm{H}} 6.46(2 \mathrm{H}, s, \mathrm{ArH})$ assigned to the equivalent protons $\mathrm{H} 2 / \mathrm{H} 6$ of ring $\mathrm{B}$ showed correlation with the signal at $\delta_{\mathrm{C}} 105.4(\mathrm{C} 2 / \mathrm{C} 6)$ in the HETCOR spectrum. The HMBC spectrum showed the correlation of the signal at $\delta_{\mathrm{H}} 6.46(\mathrm{H} 2 / \mathrm{H} 6)$ with the signals at $\delta_{\mathrm{C}} 153.2(\mathrm{C} 3 / \mathrm{C} 5)$, $136.9(\mathrm{C} 4), 105.4(\mathrm{C} 2 / \mathrm{C} 6)$ and $30.6(\mathrm{C} \beta)$. The assignment of the protons and carbons signals of ring A was proposed from the analysis of ${ }^{1} \mathrm{H} \times{ }^{1} \mathrm{H}-\mathrm{COSY}$ and HETCOR spectra.
The HETCOR spectrum showed the correlations of signals at $\delta_{\mathrm{C}} 128.6\left(\mathrm{C}^{\prime} / \mathrm{C}^{\prime}\right) 128.0\left(\mathrm{C}^{\prime} / \mathrm{C}^{\prime}{ }^{\prime}\right)$ and $133.1\left(\mathrm{C}^{\prime}{ }^{\prime}\right)$ with the signals at $\delta_{\mathrm{H}} 7.96\left(\mathrm{H}^{\prime} / \mathrm{H} 6^{\prime}\right), 7.45\left(\mathrm{H}^{\prime} / \mathrm{H}^{\prime}{ }^{\prime}\right)$ and 7.56 (H4'), respectively. The HMBC spectrum showed correlation of the signal at $\delta_{\mathrm{H}} 7.45\left(\mathrm{H}^{\prime} / \mathrm{H} 5{ }^{\prime}\right)$ with signals at $\delta_{\mathrm{C}} 128.6\left(\mathrm{C} 2^{\prime} / \mathrm{C} 6{ }^{\prime}\right)$ and $\delta_{\mathrm{C}} 136.9\left(\mathrm{C}^{\prime}{ }^{\prime}\right)$ and of the signal at $\delta_{\mathrm{H}} 7.96\left(\mathrm{H}^{\prime} / \mathrm{H}^{\prime}\right)$ ) with the signals at $\delta_{\mathrm{C}} 128.0\left(\mathrm{C}^{\prime} / \mathrm{C}^{\prime}{ }^{\prime}\right)$, 133.1 (C4') and $199.2(\mathrm{C}=\mathrm{O})$.

Compound $\mathbf{6}$ was identified as 2,3,4,4'-tetramethoxydihdrochalcone. The analysis of LR-MS spectrum of $\mathbf{6}$ showed a molecular ion peak at $m / 2330(82 \%)$ and the peaks at $m / z 195(24 \%), 181$ (98\%), $166(48 \%), 135(100 \%)$ and 107 (16\%), which are consistent with the molecular formula $\mathrm{C}_{19} \mathrm{H}_{22} \mathrm{O}_{5}$ (9 degrees of insaturation). This molecular formula was confirmed on the basis of HRESIMS $[\mathrm{m} / 2,353.1358$ $(\mathrm{M}+\mathrm{Na})^{+} ; \Delta+0.7 \mathrm{mmu}$ analysis and NMR data (Table 1). The ${ }^{1} \mathrm{H}$ NMR spectrum of $\mathbf{6}$ showed signals attributed to the benzylic methylene protons $\mathrm{H} \beta$ and $\mathrm{H} \alpha$ similar to those of compound 5. Two ortho-related doublets in the aromatic region $(1 \mathrm{H} \mathrm{each,} J 8.4 \mathrm{~Hz})$ at $\delta_{\mathrm{H}} 6.87$ and 6.59 , were assigned to $\mathrm{H} 6$ and $\mathrm{H} 5$, respectively. The signal at $\delta_{\mathrm{H}} 6.59$ correlated with the signals of carbons at $\delta_{\mathrm{C}} 127.2$ and 142.3 in the

Table 1. ${ }^{1} \mathrm{H}$ and ${ }^{13} \mathrm{C}$ NMR chemical shifts $\left(\delta_{\mathrm{H}}\right.$ and $\delta_{\mathrm{C}}$ in ppm) of compounds 5 and $\mathbf{6}$ in $\mathrm{CDCl}_{3}^{\mathrm{a}, \mathrm{b}}$

\begin{tabular}{|c|c|c|c|c|c|c|}
\hline \multirow[t]{2}{*}{ Position } & \multicolumn{3}{|c|}{5} & \multicolumn{3}{|c|}{6} \\
\hline & $\delta_{\mathrm{H}}$ & $\delta_{\mathrm{C}}$ & $\mathrm{HMBC}^{\mathrm{c}}$ & $\delta_{\mathrm{H}}$ & $\delta_{\mathrm{C}}$ & HMBC \\
\hline 1 & & $137.1^{\mathrm{d}}$ & & & 127.2 & $5,6, \alpha$ \\
\hline 2 & $6.46(\mathrm{~s})$ & 105.4 & $6, \beta$ & & 151.9 & OMe-2 \\
\hline 3 & & 153.2 & 2,OMe-3 & & 142.3 & 5 \\
\hline 4 & & $136.9^{\mathrm{d}}$ & $2,6, \mathrm{OMe}-4$ & & 152.3 & $6, \mathrm{OMe}-4$ \\
\hline 5 & & 153.2 & $6, \mathrm{OMe}-5$ & $6.59(\mathrm{~d}, 1 \mathrm{H}, J 8.4)$ & 107.2 & \\
\hline 6 & 6.46 & 105.4 & $2, \beta$ & $6.87(\mathrm{~d}, 1 \mathrm{H}, J 8.4)$ & 123.9 & 3 \\
\hline$\alpha$ & $3.29(\mathrm{t}, 2 \mathrm{H}, J 7.5)$ & 40.6 & $\beta$ & $3.18(\mathrm{t}, 2 \mathrm{H}, J 8.4)$ & 39.5 & $\beta$ \\
\hline$\beta$ & $3.01(\mathrm{t}, 2 \mathrm{H}, J 7.5)$ & 30.6 & $2,6, \alpha$ & $2.96(\mathrm{t}, 2 \mathrm{H}, J 8.4)$ & 25.3 & $6, \alpha$ \\
\hline $\mathrm{C}=\mathrm{O}$ & & 199.2 & $2^{\prime}, 6$ & & 198.4 & $\alpha, \beta, 2^{\prime}, 6^{\prime}$ \\
\hline 1 ' & & 136.9 & $3^{\prime}, 5^{\prime}$ & & 129.9 & \\
\hline 2 ' & $7.96(\mathrm{dd}, 2 \mathrm{H}, J 7.5$ and 1.5$)$ & 128.6 & 6 ' & $7.95(\mathrm{~d}, 2 \mathrm{H}, J 9.3)$ & 130.6 & $3^{\prime}, 6^{\prime}$ \\
\hline $3^{\prime}$ & $7.45(\mathrm{t}, 2 \mathrm{H}, J 7.5)$ & 128.0 & & $6.92(\mathrm{~d}, 2 \mathrm{H}, J 9.3)$ & 113.6 & \\
\hline 4 ' & $7.56(\mathrm{tt}, 1 \mathrm{H}, J 13.2,7.5$ and 1.5$)$ & 133.1 & $2^{\prime}, 6{ }^{\prime}$ & & 163.3 & 2', 6', OMe-4' \\
\hline 5 & $7.45(\mathrm{t}, 2 \mathrm{H}, J 7.5)$ & 128.0 & & $6.92(\mathrm{~d}, 2 \mathrm{H}, J 9.3)$ & 113.6 & \\
\hline $6^{\prime}$ & $7.96(\mathrm{dd}, 2 \mathrm{H}, J 1.5$ and 7.5$)$ & 128.6 & $2^{\prime}$ & $7.95(\mathrm{~d}, 2 \mathrm{H}, J 9.3)$ & 130.6 & $2^{\prime}, 5^{\prime}$ \\
\hline OMe-2 & & & & $3.90(\mathrm{~s})$ & 60.8 & \\
\hline OMe-3 & $3.84(\mathrm{~s})$ & 56.1 & & $3.88(\mathrm{~s})$ & 60.6 & \\
\hline OMe-4 & $3.82(\mathrm{~s})$ & 60.8 & & $3.83(\mathrm{~s})$ & 55.3 & \\
\hline OMe-5 & $3.84(\mathrm{~s})$ & 56.1 & & & & \\
\hline OMe-4' & & & & $3.85(\mathrm{~s})$ & 55.9 & \\
\hline
\end{tabular}

${ }^{\mathrm{a}}{ }^{1} \mathrm{H}$ NMR data were recorded at $300 \mathrm{MHz} .{ }^{\mathrm{b}}{ }^{13} \mathrm{C}$ NMR data were recorded at $75 \mathrm{MHz} .{ }^{\mathrm{c}}{ }^{1} \mathrm{H}-{ }^{13} \mathrm{C}$ HMBC correlations are from the carbon(s) specified to the protons indicated. ${ }^{\mathrm{d}}$ Values can be reversed. 
HMBC spectra, what allowed the assignment of these signals to $\mathrm{C} 1$ and $\mathrm{C} 3$, respectively. In the same NMR spectrum, it was observed that the signal at $\delta_{\mathrm{H}} 6.87(\mathrm{H} 6)$ showed correlation with the signals at $\delta_{\mathrm{C}} 151.9$ and 152.3 , which indicated that these signals can be attributed to $\mathrm{C} 2$ and $\mathrm{C} 4$ carbons, respectively. The analysis of the HETCOR $\left({ }^{1} J_{\mathrm{CH}}\right)$ spectrum of $\mathbf{6}$ confirms the assignments of the signals of the protons $\mathrm{H} 5$ and $\mathrm{H} 6$, since they showed correlations with the signals of carbons at $\delta_{\mathrm{C}} 107.2$ (C5) and $123.9(\mathrm{C} 6)$. The ${ }^{1} \mathrm{H}$ NMR spectrum showed two ortho-related doublets at $\delta_{\mathrm{H}} 7.95$ and $6.92(2 \mathrm{H}$ each, $J 8.4 \mathrm{~Hz}$ ), due to the protons of a system AA'-XX', assigned to $\mathrm{H}^{\prime} / \mathrm{H} 6^{\prime}$ and $\mathrm{H} 3^{\prime} / \mathrm{H} 5$ ', respectively. This coupling was confirmed by analysis of spectrum ${ }^{1} \mathrm{H} \times{ }^{1} \mathrm{H}-\mathrm{COSY}$. The analysis of HETCOR spectrum of $\mathbf{6}$, relating to the ring $\mathrm{A}$, was important to assign accurately the signals at $\delta_{\mathrm{C}} 130.3$ and 113.6 to carbons $\mathrm{C}^{\prime} / \mathrm{C} 6$ ' and $\mathrm{C}^{\prime} / \mathrm{C} 5$ ', respectively, that showed ${ }^{1} J_{\mathrm{CH}}$ correlations with signals at $\delta_{\mathrm{H}} 7.95$ and 6.92. The HMBC spectrum showed correlations of the signals of carbons at $\delta_{\mathrm{C}} 129.9\left(\mathrm{C} 1^{\prime}\right)$ and $163.3\left(\mathrm{C}^{\prime}\right.$ ') with the signals at $\delta_{\mathrm{H}} 6.92\left(\mathrm{H}^{\prime} / \mathrm{H} 55^{\prime}\right)$ and $\delta_{\mathrm{H}} 7.95\left(\mathrm{H}^{\prime} / \mathrm{H}^{\prime}\right.$ '). The assignment of carbonyl carbon signal $\left(\delta_{\mathrm{C}} 198.4\right)$ was based on the analysis of the correlations with the signals due to $\mathrm{H} \beta$ and $\mathrm{H} \alpha$.

\section{Experimental}

\section{General experimental procedures}

Low-resolution mass spectra data were obtained on a Thermo DSQII GC-MS instrument equipped with fused silica capillary column $(30 \mathrm{~m} \times 0.25 \mathrm{~mm}$ id $)$ with DB-5MS stationary phase $(0.25 \mathrm{mu}$ thickness of the film); carrier gas helium gas, temperature of the source and other parts $200^{\circ} \mathrm{C}$; type of injection: splitless; programmed temperature to $100-300^{\circ} \mathrm{C}$, with a gradient of $5^{\circ} \mathrm{C} \mathrm{min}^{-1}$. The quadrupole filter swept range 39-400 daltons every second. Ionization was obtained by the technique of electron impact with energy of $70 \mathrm{eV}$, and high resolution mass spectra were recorded on an LC-IT-TOF mass spectrometer model 225-07100-34-SHIMADZU, by positive ionization mode of the ESI. NMR spectra, including HMBC experiment, were recorded on a Varian Mercury-300 spectrometer, operating at $300 \mathrm{MHz}$ for ${ }^{1} \mathrm{H}$ and $75 \mathrm{MHz}$ for ${ }^{13} \mathrm{C} \mathrm{NMR}$, using solvent signal (d-chloroform) as reference. The chemical shifts are given in delta $(\delta)$ values and the coupling constants $(J)$ in Hertz (Hz).

\section{Plant material}

The leaves of Paspalum maritimum were collected in January 2009 in the forest reserve of EMBRAPA-Amazônia
Oriental in Belém, Pará State, Brazil. A voucher specimen (IAN 183337) was deposited at the herbarium of this institution.

\section{Microorganisms and culture}

The general procedures adopted for isolation of the microorganism followed the methodology described by Araújo et $a l .{ }^{34}$ Epiphytic hyphae and spores were eliminated by immersion of the plant material in 70\% ethanol (1 min), followed by $5 \%$ aqueous sodium hypochlorite (4 min) and finally with $70 \%$ aqueous ethanol ( $30 \mathrm{~s}$ ), before being rinsed in sterile distilled water. The material was then deposited on a Petri dish containing Sabouraud (SDA), composition meat peptone $10 \mathrm{~g} \mathrm{~L}^{-1}$ (HIMEDIA), D-glucose anhydrous $20.0 \mathrm{~g} \mathrm{~L}^{-1}$ (NUCLEAR), Agar $20.0 \mathrm{~g} \mathrm{~L}^{-1}$ (VETEC) and chloramphenicol $1.0 \mathrm{~g} \mathrm{~L}^{-1}$ and incubated in the dark at $30{ }^{\circ} \mathrm{C}$. Samples of the fast growing fungi were subcultured onto other plates with the culture medium used. The microorganisms were conserved as suspension in distilled water. The aflpm3D1 strain was identified as Aspergillus flavus by Dra. Maria Inês de Moura Sarquis, Fiocruz-RJ. A voucher specimen has been deposited at "Laboratório de Química de Microorganismos e Bioensaios-UFPA".

\section{Synthesis of substrate: ${ }^{18}$ chalcones 1-3}

In a flat-bottomed flask $(125 \mathrm{~mL})$, placed in an ice bath, $15 \mathrm{~mL}$ of EtOH, $11 \mathrm{mmol}$ of acetophenone or derivatives, $15 \mathrm{~mL}$ of $10 \% \mathrm{NaOH}$ solution and $12 \mathrm{mmol}$ of benzaldehyde or derivatives were added. The reaction mixture was kept on magnetic stirring at $40{ }^{\circ} \mathrm{C}$ for $40 \mathrm{~min}$. After this period, the mixture was cooled and left in freezer for $48 \mathrm{~h}$ and then filtered under vacuum. The product was crystallized in methanol. Chalcone 1 was obtained in $68.5 \%$ yield $(1.47 \mathrm{~g})$, chalcone 2 was obtained in $75.0 \%$ yield $(2.42 \mathrm{~g})$ and chalcone 3 was obtained in $60.0 \%$ yield $(2.62 \mathrm{~g})$.

\section{General procedure for biotransformation reactions}

One Erlenmeyer flask $(250 \mathrm{~mL})$, containing $100 \mathrm{~mL}$ SDA modified medium (meat peptone $10 \mathrm{~g} \mathrm{~L}^{-1}$ (HIMEDIA), D-glucose anhydrous $10 \mathrm{~g} \mathrm{~L}^{-1}$ (NUCLEAR) and chloramphenicol $1.0 \mathrm{~g} \mathrm{~L}^{-1}$ ) was previously autoclaved at $121{ }^{\circ} \mathrm{C}$ for $15 \mathrm{~min}$. Three small disc cut from Petri dishes containing mycelium of A. flavus in SDA medium and the appropriate chalcones (1-3), $0.05 \mathrm{~g}$ dissolved in $0.5 \mathrm{~mL}$ DMSO, were added under steril conditions to the Erlenmeyer flask and shaken $(160 \mathrm{rpm})$ at $30{ }^{\circ} \mathrm{C}$. After 10 days the reaction mixture was extracted with EtOAc $(3 \times 100 \mathrm{~mL})$, and organic phases were grouped, dried $\left(\mathrm{Na}_{2} \mathrm{SO}_{4}\right)$, filtered 
and evaporated at reduced pressure. Experiments were performed in triplicate and were reproducible according to TLC analysis. Control flasks consisted of cultures containing substrate in DMSO without fungus and cultures containing fungus and DMSO without substrate. The purifications were carried out from one experiment. The crude residue $(102.0 \mathrm{mg})$ obtained from the biotransformation reaction of chalcone $\mathbf{1}$ was chromatographed on silica gel by elution with EtOAc $(300 \mathrm{~mL})$ and $\mathrm{MeOH}(100 \mathrm{~mL})$. Evaporation of solvent furnished EtOAc extract $(62.0 \mathrm{mg})$ and $\mathrm{MeOH}$ extract $(30.6 \mathrm{mg})$. TLC analysis indicated that the substances of interest were in the extract EtOAc. This extract was chromatographed sequentially on silica gel eluting with hexanes and increasing polarity with EtOAc, to give eleven fractions (A1-A11). Fractions A3-A5 (hexanes:EtOAc 9:1; 8:2 and 8:2, respectively) were grouped and recrystallized with $\mathrm{MeOH}$ giving dihydrochalcone 4 (37.2 mg). The crude residues obtained from the biotransformation reactions of chalcones $\mathbf{2}$ and $\mathbf{3}$ after the same treatment, provided EtOAc extract $(113.0 \mathrm{mg})$ and $\mathrm{MeOH}$ extract $(90.6 \mathrm{mg})$ to the chalcone 2 reaction, and EtOAc extract $(119.0 \mathrm{mg})$ and $\mathrm{MeOH}$ extract $(97.3 \mathrm{mg}$ ) to the chalcone 3 reaction. The EtOAc extract obtained from the biotransformation reactions of chalcone $\mathbf{2}$ was chromatographed sequentially on silica gel eluting with hexanes and increasing polarity with EtOAc, to give fourteen fractions (B1-B14). Fractions B6-B10 (hexanes:EtOAc 8:2; 8:2; 7:3; 7:3 and 6:4, respectively) were grouped and recrystallized with $\mathrm{MeOH}$ giving dihydrochalcone $5(18.3 \mathrm{mg})$. The EtOAc extract obtained from the biotransformation reactions of chalcone $\mathbf{3}$ was chromatographed sequentially on silica gel eluting with hexanes and increasing polarity with EtOAc, to give seventeen fractions (C1-C17). Fractions C12 (hexane:EtOAc 6:4) and $\mathrm{C} 13$ (hexane:EtOAc 6:4) were grouped and recrystallized with $\mathrm{MeOH}$ giving dihydrochalcone $\mathbf{6}(7.8 \mathrm{mg})$.

\section{3,4,5-Trimethoxydihydrochalcone (5)}

Crystalline solid; mp 59-61 ${ }^{\circ} \mathrm{C}(\mathrm{MeOH}) ;{ }^{1} \mathrm{H}$ NMR (300 MHz, $\mathrm{CDCl}_{3}$ ): see Table $1 ;{ }^{13} \mathrm{C}$ NMR $(75 \mathrm{MHz}$, $\mathrm{CDCl}_{3}$ ): see Table 1. LR-MS: $\mathrm{m} / \mathrm{z}$ (rel. int.): 300 (64), 195 (100), 181 (36), 165 (42), 77 (36). HRESIMS [M+Na]+; Found: $323.1270[\mathrm{M}+\mathrm{Na}]^{+}$; Calc. for $\mathrm{C}_{18} \mathrm{H}_{20} \mathrm{O}_{4} \mathrm{Na}$ : 323.1259 .

\section{2,3,4,4'-Tetramethoxydihydrochalcone (6)}

Crystalline solid; mp 75-77 ${ }^{\circ} \mathrm{C}(\mathrm{MeOH}) ;{ }^{1} \mathrm{H}$ NMR (300 MHz, $\mathrm{CDCl}_{3}$ ): see Table $1 ;{ }^{13} \mathrm{C}$ NMR $(75 \mathrm{MHz}$, $\mathrm{CDCl}_{3}$ ): see Table 1. LR-MS: $m / z$ (rel. int.): 330 (82), 195 (24), 181 (98), 166 (48), 135 (100), 107 (16). HRESIMS $[\mathrm{M}+\mathrm{Na}]^{+}$Found: $353.1358[\mathrm{M}+\mathrm{Na}]^{+}$; Calc. for $\mathrm{C}_{19} \mathrm{H}_{22} \mathrm{O}_{5} \mathrm{Na}$ : 353.1365 .

\section{Conclusions}

Microbial transformation is an effective tool for the structural modification of bioactive natural and synthetic compounds, including chalcones. Microbial factories pose advantages such as rapid growth, ease of cultivation, convenient genetic manipulations, and high level production on natural products biotransformation. Moreover, microbial production increases product selectivity and reduces the usage of toxic chemicals while conserving energy usage. The use of microorganisms in bioreduction reactions of chalcones has led to the formation of several products in mixture, formed by cyclization, reduction, $O$-demethylation, hydroxilation reactions, among others. Generally, these reactions have shown low yield and stereoselectivity. In this work we performed the biotransformation reaction of chalcones to dihydrochalcones in excellent yields, compared to other biotransformation reactions of flavonoids. The bioreduction reaction was regioselective, showing only alteration in carbon-carbon double bond of the olefin, not occurring any alteration in the carbonyl double bond of the $\alpha, \beta$-unsaturated ketone system. In addition, to the best of our knowledge this is the first report of the obtention of dihydrochalcones directly from biotransformation reaction of chalcones.

\section{Supplementary Information}

Supplementary Information (Figure S1-S19) is available free of charge at http://jbcs.org.br as PDF file.

\section{Acknowledgments}

The authors would like to thank CAPES, CNPq and FAPESPA for financial support; Dra. Maria Inês de Moura Sarquis (Fiocruz-RJ) by identification of the fungus; Laboratory of Mass Spectrometry of Northeast (LEMANOR) by acquisition of mass spectra (LCMS-ITTOF: quadrupole ion trap-time of flight mass spectrometer).

\section{References}

1. Demain, A. L.; Appl. Microbiol. Biotechnol. 1999, 52, 455.

2. Schmid, A.; Dordick, J. S.; Hauer, B.; Wubbolts, M.; Witholt, B.; Nature 2001, 409, 258.

3. Faber, K.; Biotransformations in Organic Chemistry, $4^{\text {th }}$ ed.; Springer: Berlim, 2000.

4. Davis, B. G.; Boyer, V.; Nat. Prod. Rep. 2001, 18, 618.

5. Comasseto, J. V.; Omori, A. T.; Porto, A. L. M.; Andrade, L. H.; Tetrahedron Lett. 2004, 45, 473. 
6. Comasseto, J. V.; Andrade L. H.; Omori, A. T.; Assis, L. F.; Porto, A. L. M.; J. Mol. Catal. B: Enzym. 2004, 29, 55.

7. Kamerbeek, N. M.; Moonen, M. J. H.; van der Vem, J. G. M.; van Berkel, W. J. H.; Fraaije, M. W.; Janssen, D. B.; Eur. J. Biochem. 2001, 268, 2547.

8. Andrade, L. H.; Keppler, A. F.; Crusius-Schoenlein, I. H.; Porto, A. L. M.; Comasseto, J. V.; J. Mol. Catal. B: Enzym. 2004, 31, 129.

9. Gotor-Fernandez, V.; Brieva, R.; Gotor, V.; J. Mol. Catal. B: Enzym. 2006, 40, 111.

10. Pinheiro, S.; Ferreira, V. F.; Quim. Nova 1998, 21, 312.

11. Ogawa, J.; Shimizu, S.; Curr. Opin. Biotechnol. 2002, 13, 367.

12. Sahoo, S.; Kumar, P.; Lefebvre, F,; Halligudi, F. B.; Appl. Catal., A 2009, 354, 17.

13. Wang, P.-Y.; Tsai, S.-W.; J. Mol. Catal. B: Enzym. 2009, 59, 70.

14. Ishitsuka, H.; Ninomiya, Y. T.; Ohsawa, C.; Fujiu, M.; Suhara, Y.; Antimicrob. Agents Chemother. 1982, 22, 617.

15. Kiat, T. S.; Pippen, R,; Yusof, R.; Ibrahim, H.; Khalid, N.; Rahman, N. A.; Bioorg. Med. Chem. Lett. 2006, 12, 3337.

16. Phrutivorapongkul, A.; Lipipun, V.; Ruangrungsi, N.; Kirtikara, K.; Nishikawa, K.; Maruyama, S.; Watanabe, T.; Ishikawa, T.; Chem. Pharm. Bull. 2003, 51, 187.

17. Wu, J.-H.; Wang, X.-H.; Yi, Y.-H.; Lee, K.-H. Bioorg. Med. Chem. Lett. 2003, 13, 1813.

18. Bitencourt, H. R.; Santos, L. S.; Souza Filho, A. P. S.; Planta Daninha 2007, 25, 747.

19. Herencia, F.; López-Garcia, M. P.; Ubeda, A.; Ferrándiz, M. L.; Biol. Chem. 2002, 6, 242.

20. Wang, A.; Zhang, F.; Huang, L.; Yin, X.; Li, H.; Wang, Q.; Zeng, Z.; Xie, T.; J. Med. Plant. Res. 2010, 4, 847.
21. Das, S.: Rosazza, J. P. N.; J. Nat. Prod. 2006, 69, 499.

22. Buisson, D.; Quintin, J.; Lewin, G.; J. Nat. Prod. 2007, 70, 1035.

23. Kostrzewa-Suslow, E.; Dmochowska-Gladysz, L.; Bialonska, A.; Ciunik, Z.; Rymowicz, W.; J. Mol. Catal. B: Enzym. 2006, $39,18$.

24. Kinoshita, E.; Murakami, S.; Aishima, T.; J. Agric. Food Chem. 2000, 48, 2149.

25. Zhong, K.; Shao, Z.; Hong, F.; Biotechnol. Prog. 2008, 24, 583.

26. Kostrzewa-Suslowa, E.; Dmochowska-Gladysz, J.; Bialonska, A.; Ciunik, Z.; J. Mol. Catal. B: Enzym. 2008, 52, 34.

27. Annapoorna, S. R.; Rao, M. P.; Sethuram, B.; Indian J. Chem., Sect. A: Inorg., Bio-inorg., Phys., Theor. Anal. Chem. 2002, 41, 1341.

28. Edwards, M. L.; Stemerick, D. M.; Sunkara, P. S.; J. Med. Chem. 1990, 33, 1948.

29. Russell, A.; J. Chem. Soc. 1934, 218.

30. Sushma, D.; Asian J. Chem. 2007, 19, 4957.

31. Sanchez-Gonzalez, M.; Rosazza, J. P. N.; J. Nat. Prod. 2004, 67, 553

32. Shindo, K.; Kagiyama, Y.; Nakamura, R.; Hara, A.; Ikenaga, H.; Furukawa, K.; Misawa, N.; J. Mol. Catal. B: Enzymol. 2003, $23,9$.

33. Herath, W. H. M. W.; Ferreira, D.; Khan, I. A.; Phytochemistry 2003, 62, 673.

34. Araújo, W. L.; Lima, A. O. S.; Azevedo, J. L.; Marcon, J.; Sobral, J. K.; Lacava, P. T.; Manual: Isolamento de Microrganismos Endofíticos, CALQ: Piracicaba, Brazil, 2002.

Submitted: July 8, 2010

Published online: March 22, 2011 


\section{Biotransformation of Chalcones by the Endophytic Fungus Aspergillus flavus Isolated from Paspalum maritimum Trin.}

Marivaldo J. C. Corrêa, ${ }^{a}$ Fátima M. Nunes, ${ }^{a}$ Heriberto R. Bitencourt, ${ }^{a}$ Fábio C. Borges, ${ }^{a}$ Giselle M. S. P. Guilhon, ${ }^{a}$ Mara S. P. Arruda, ${ }^{a}$ Andrey M. R. Marinho, ${ }^{a}$ Alberdan S. Santos, ${ }^{a}$ Cláudio N. Alves, ${ }^{a}$ Davi S. B. Brasil ${ }^{b}$ and Lourivaldo S. Santos $*, a$

aPrograma de Pós-Graduação em Química, Instituto de Ciências Exatas e Naturais and ${ }^{b}$ Faculdade de Engenharia Química, Instituto de Tecnologia, Universidade Federal do Pará, Campus Universitário do Guamá, 66075-900 Belém-PA, Brazil

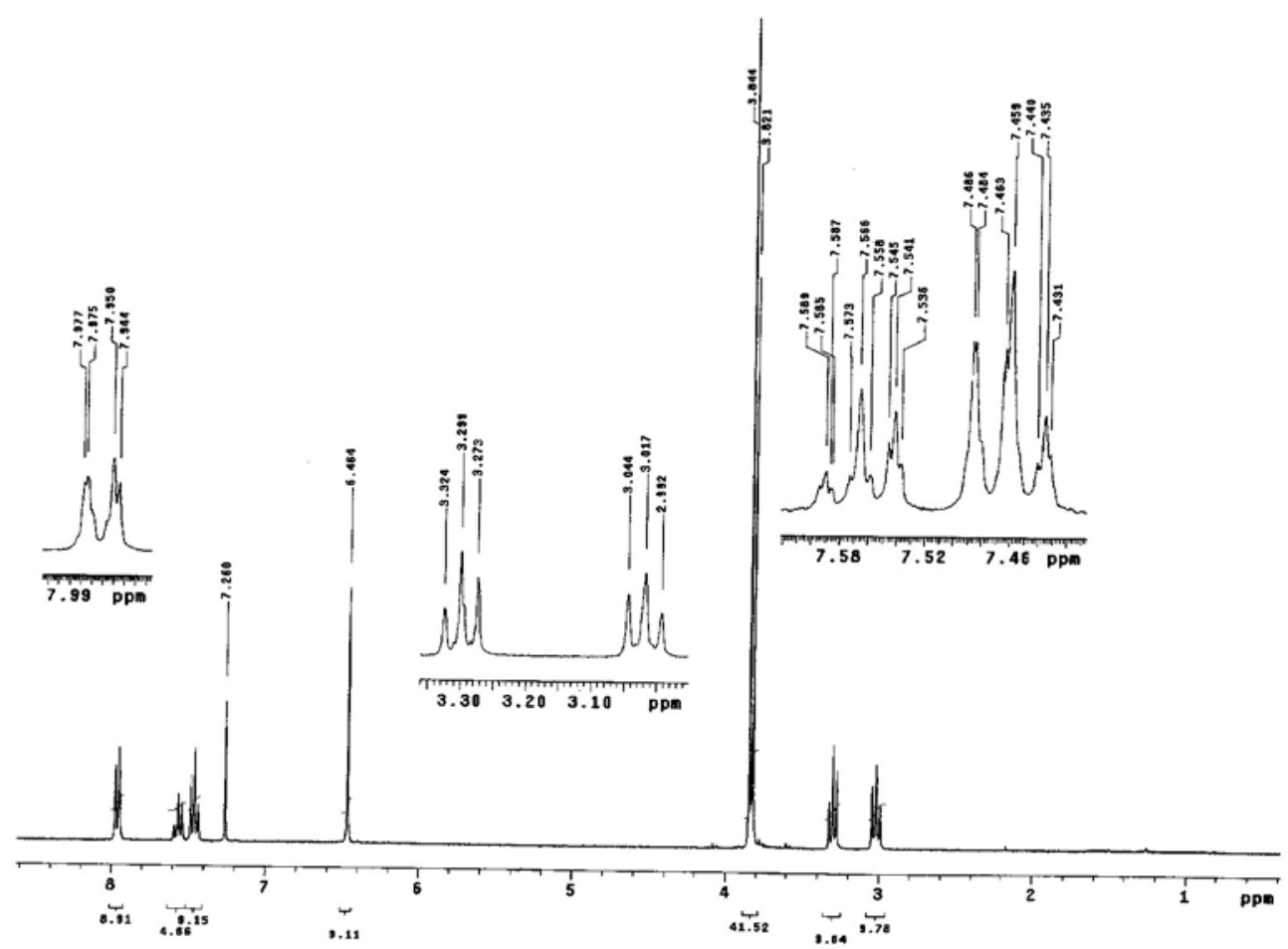

Figure S1. ${ }^{1} \mathrm{H}$ NMR spectrum ( $300 \mathrm{MHz}, \mathrm{CDCl}_{3}$ ) of compound 5 . 


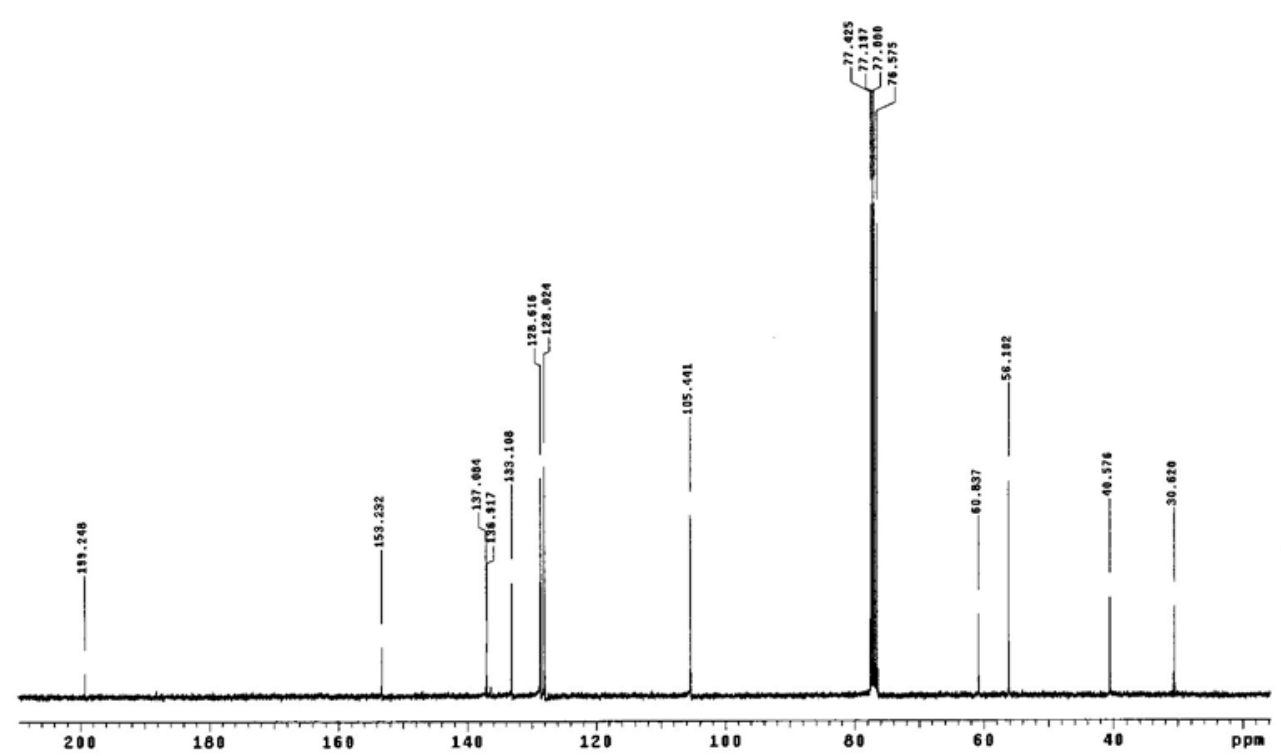

Figure S2. ${ }^{13} \mathrm{C}$ NMR spectrum $\left(75 \mathrm{MHz}, \mathrm{CDCl}_{3}\right.$ ) of compound 5 .
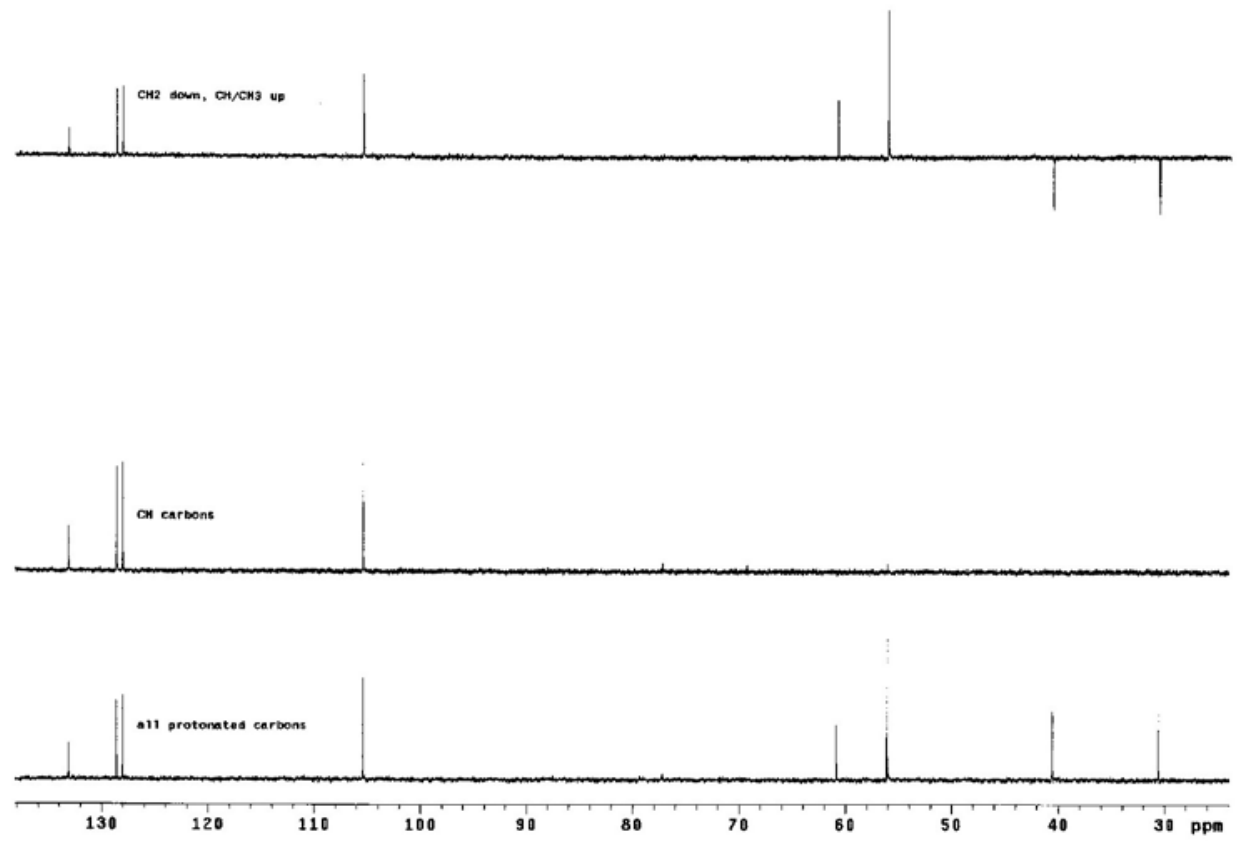

Figure S3. DEPT spectrum ( $75 \mathrm{MHz}, \mathrm{CDCl}_{3}$ ) of compound 5. 


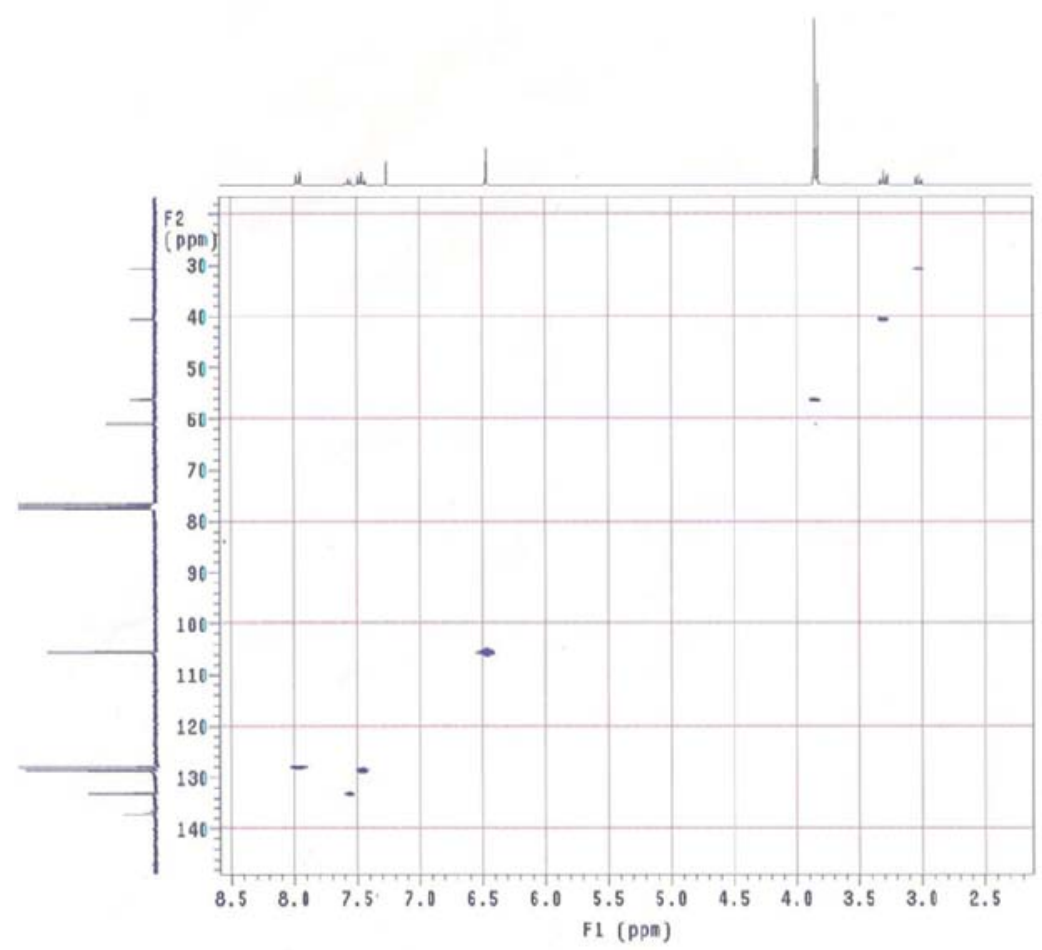

Figure S4. HETCOR spectrum $\left(\mathrm{CDCl}_{3}\right)$ of compound 5.

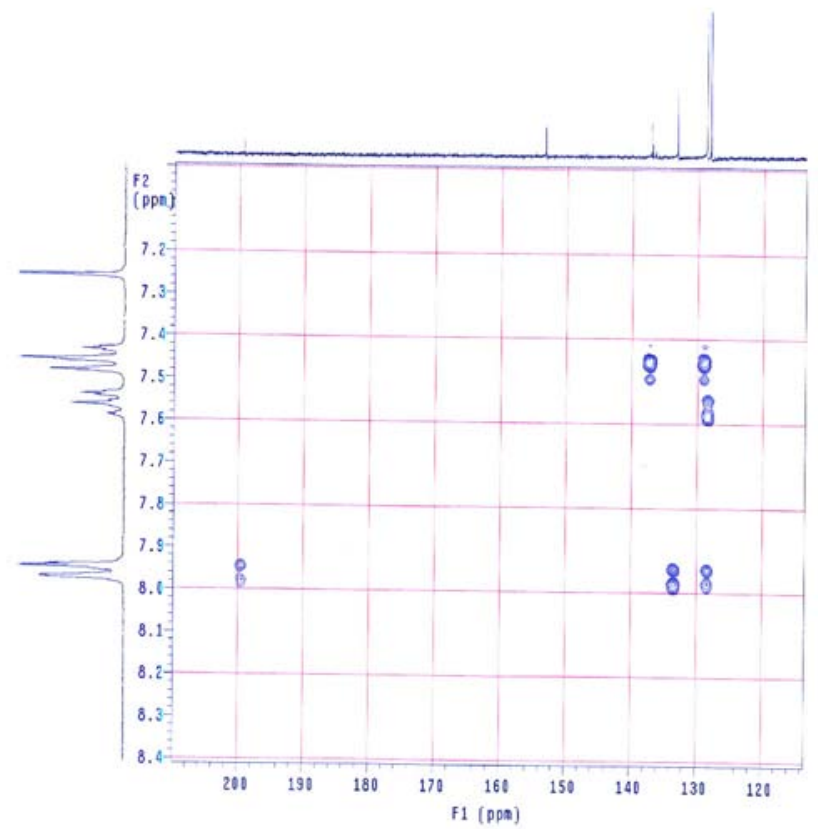

Figure S5. HMBC spectrum of compound 5 (expansion). 


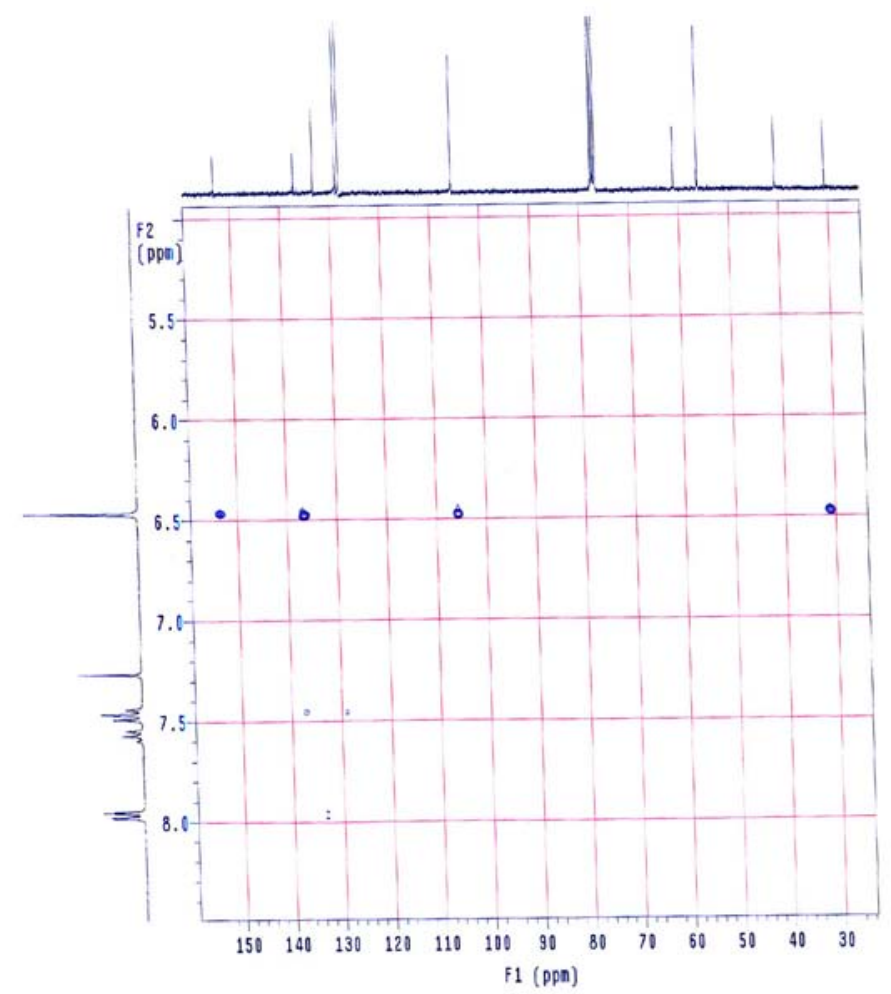

Figure S6. HMBC spectrum of compound 5 (expansion).

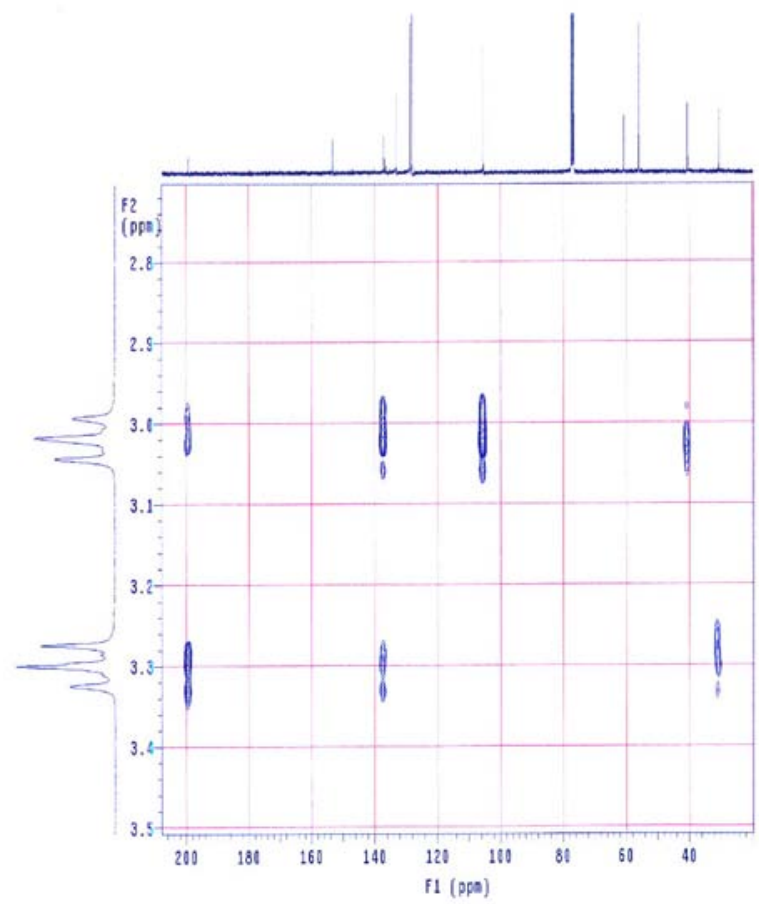

Figure S7. HMBC spectrum of compound 5 (expansion). 


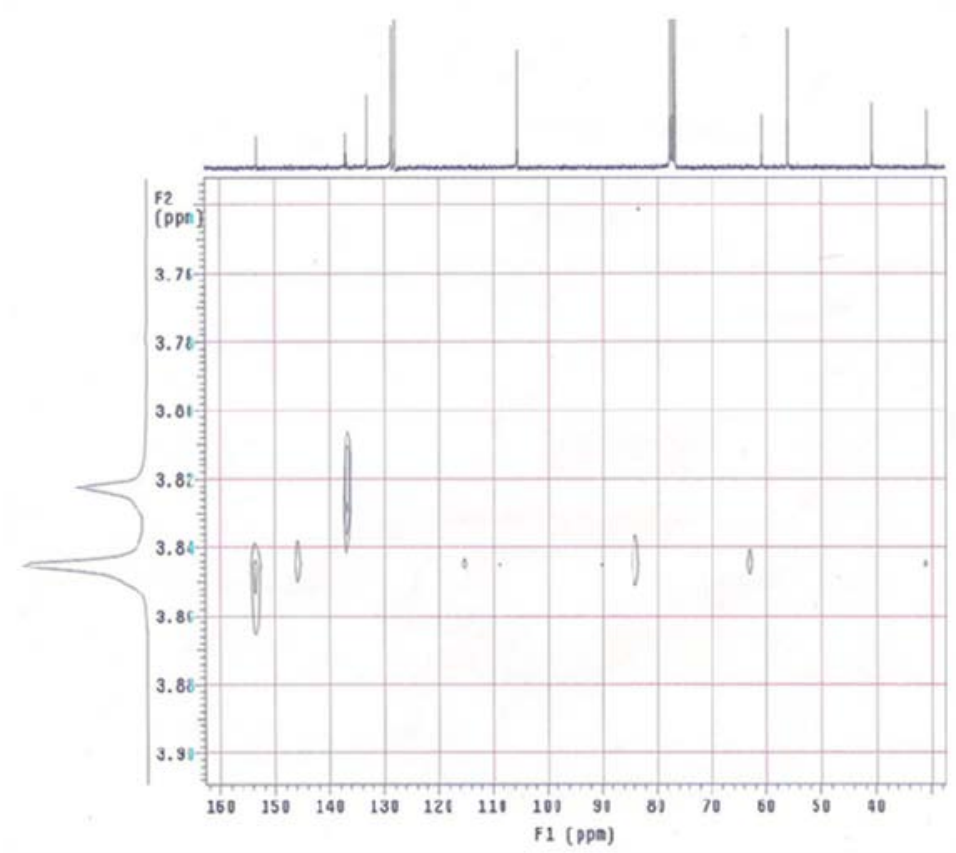

Figure S8. HMBC spectrum of compound $\mathbf{5}$ (expansion).

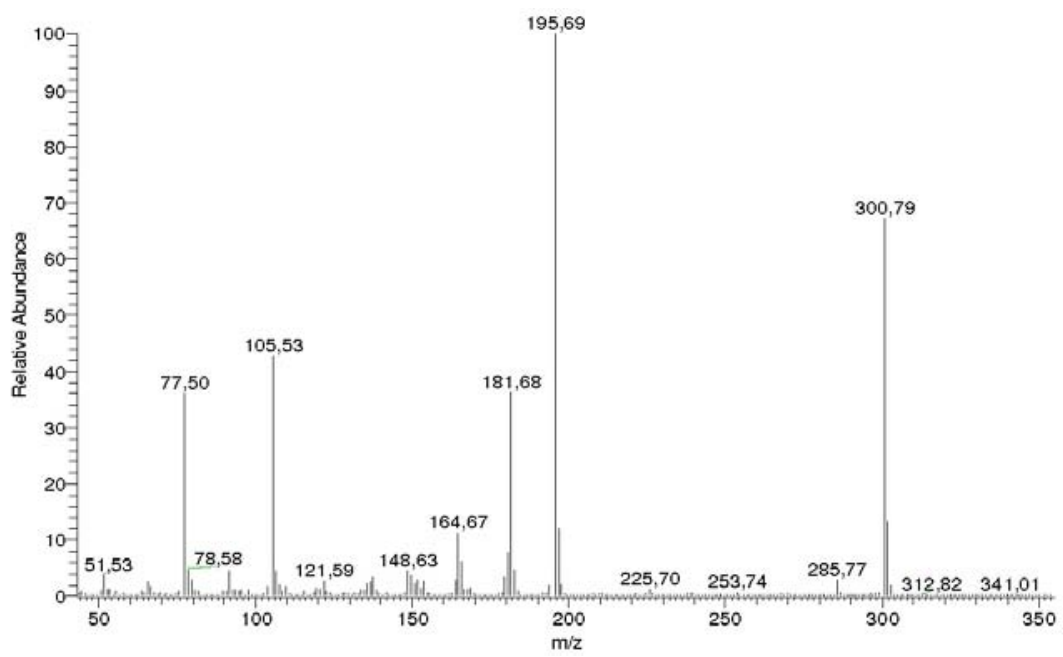

Figure S9. Low resolution mass spectrum of compound $\mathbf{5}$. 


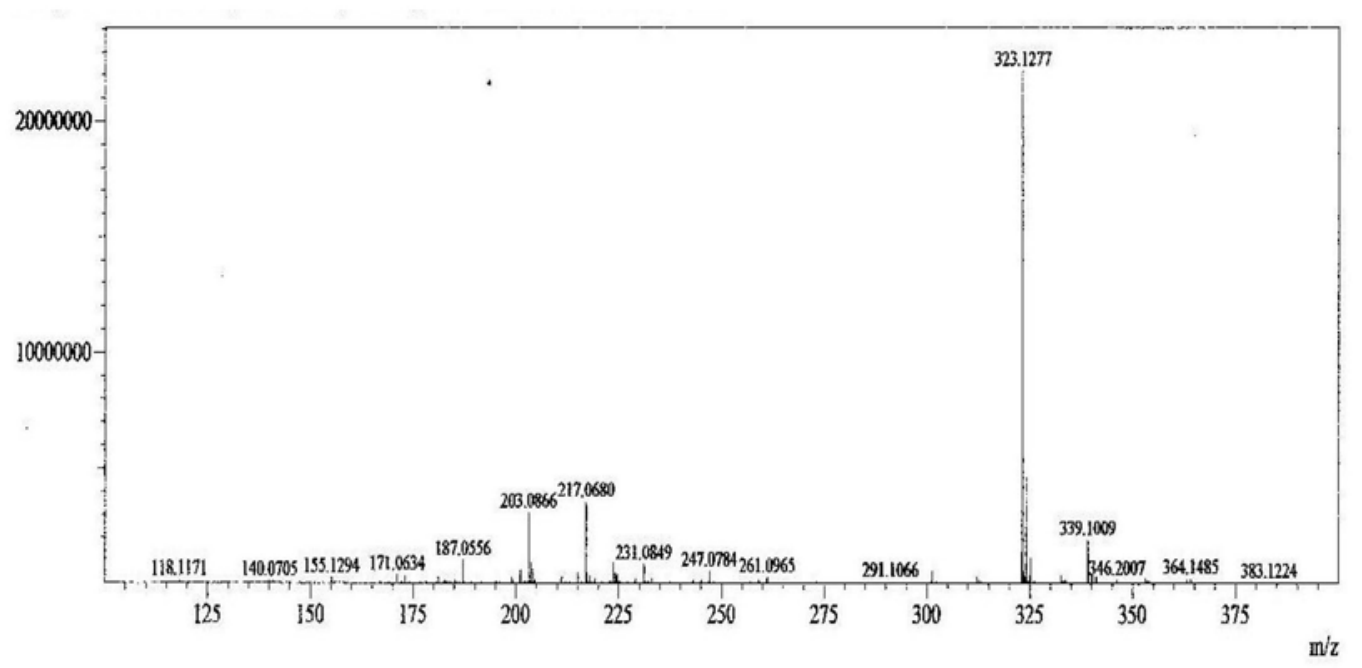

Figure S10. High resolution mass spectrum of compound $\mathbf{5}$.

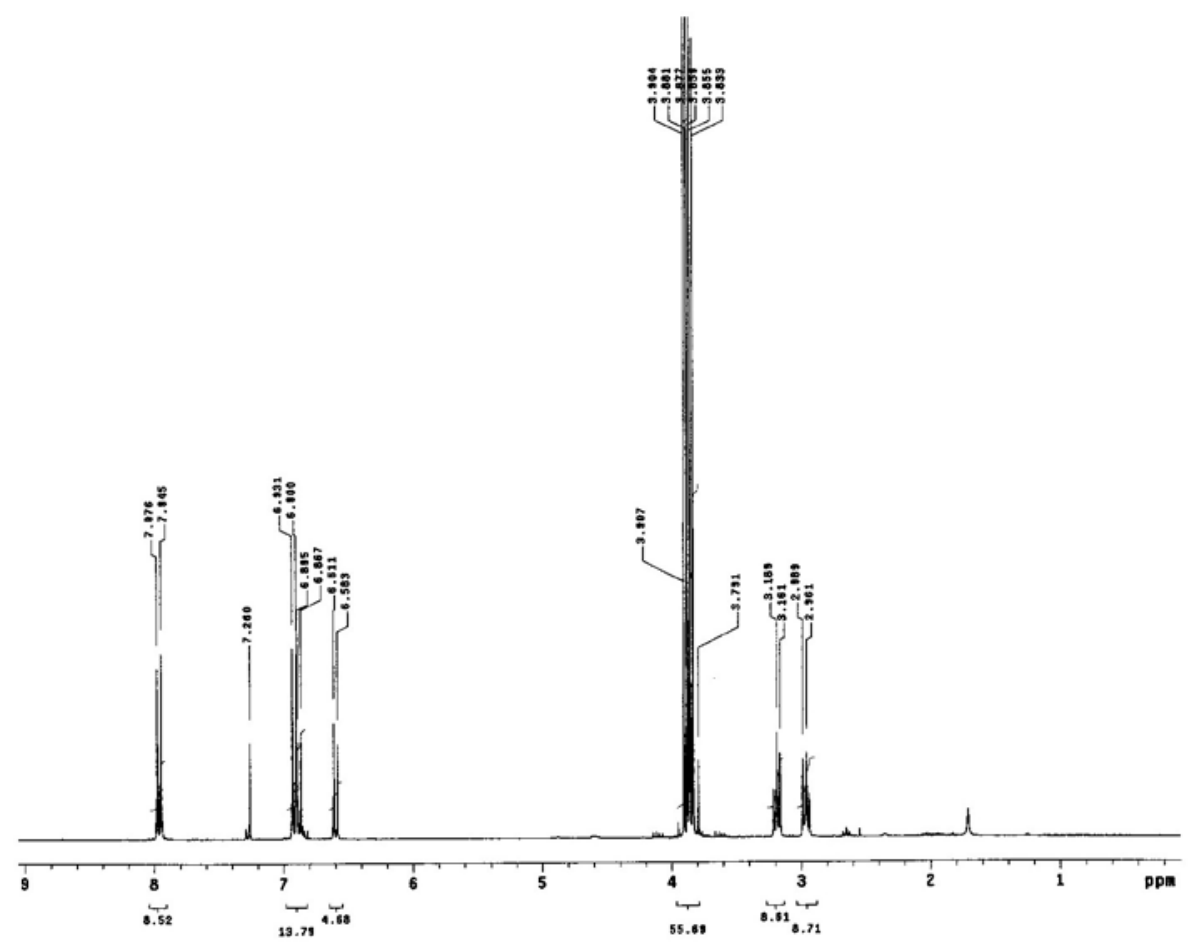

Figure S11. ${ }^{1} \mathrm{H}$ NMR spectrum $\left(300 \mathrm{MHz}, \mathrm{CDCl}_{3}\right)$ of compound 6 . 


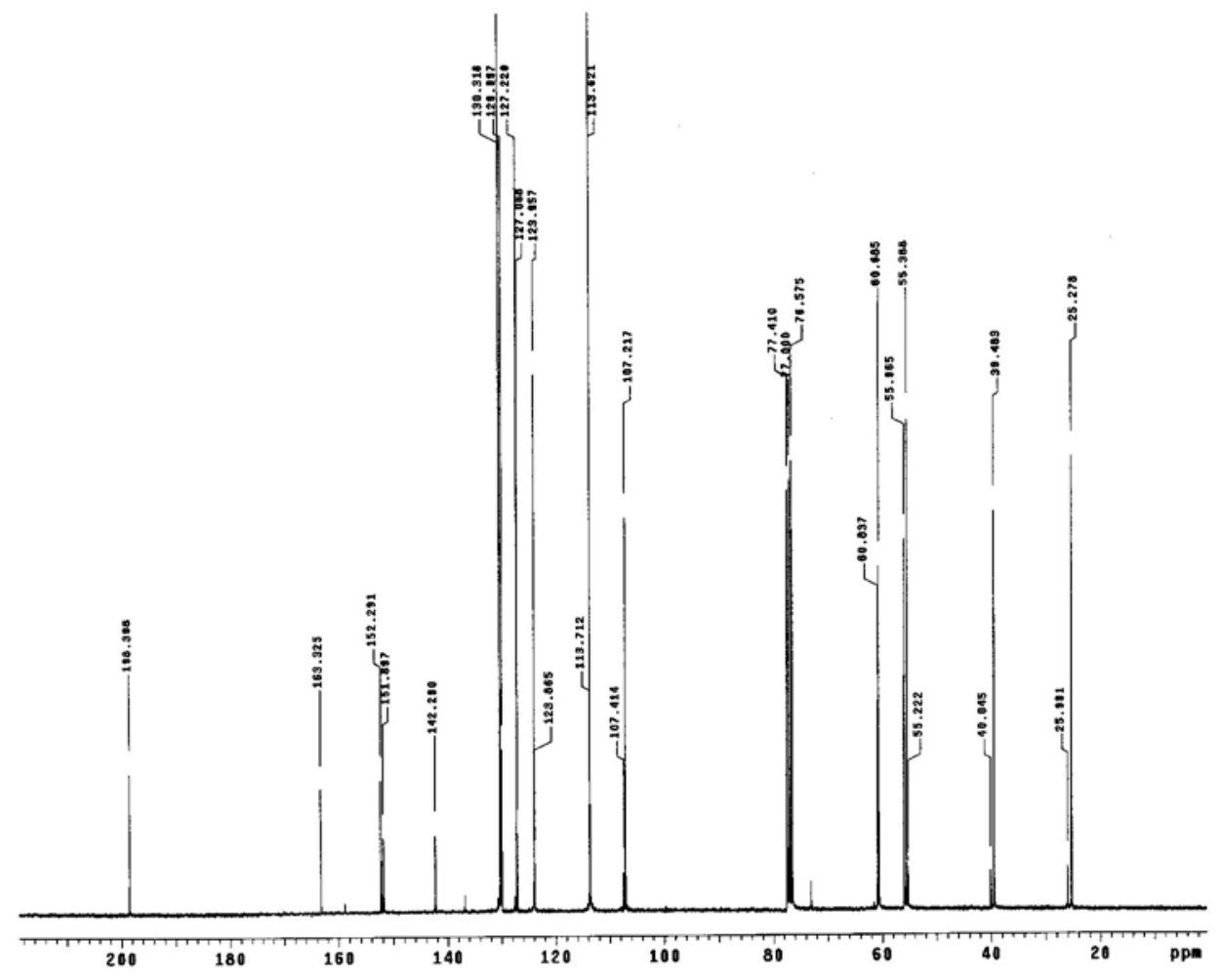

Figure S12. ${ }^{13} \mathrm{C}$ NMR spectrum ( $75 \mathrm{MHz}, \mathrm{CDCl}_{3}$ ) of compound 6 .
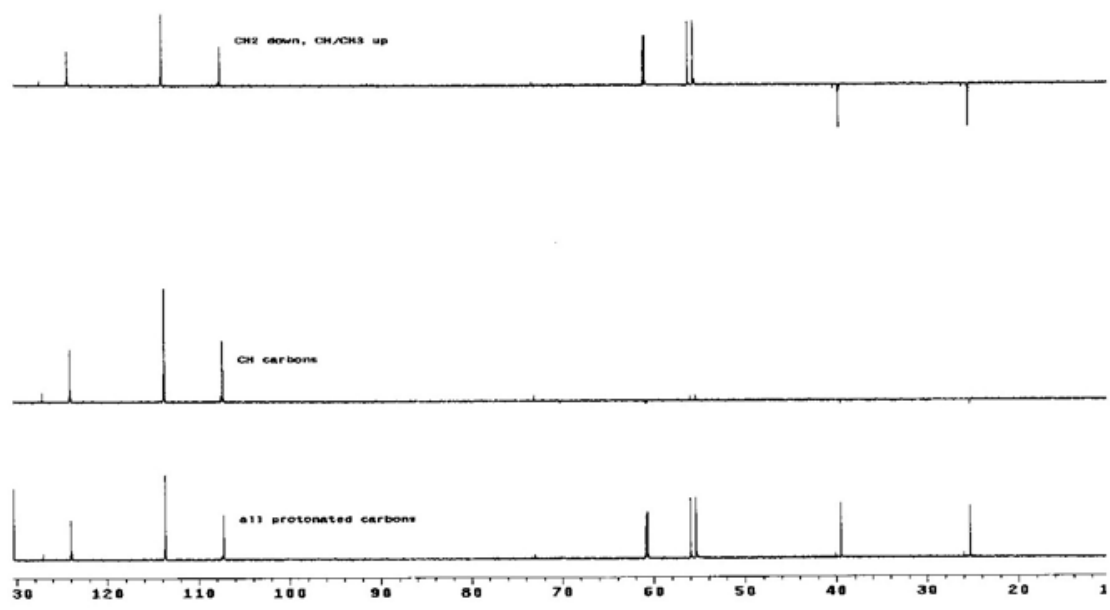

Figure S13. DEPT spectrum ( $75 \mathrm{MHz}, \mathrm{CDCl}_{3}$ ) of compound 6 . 


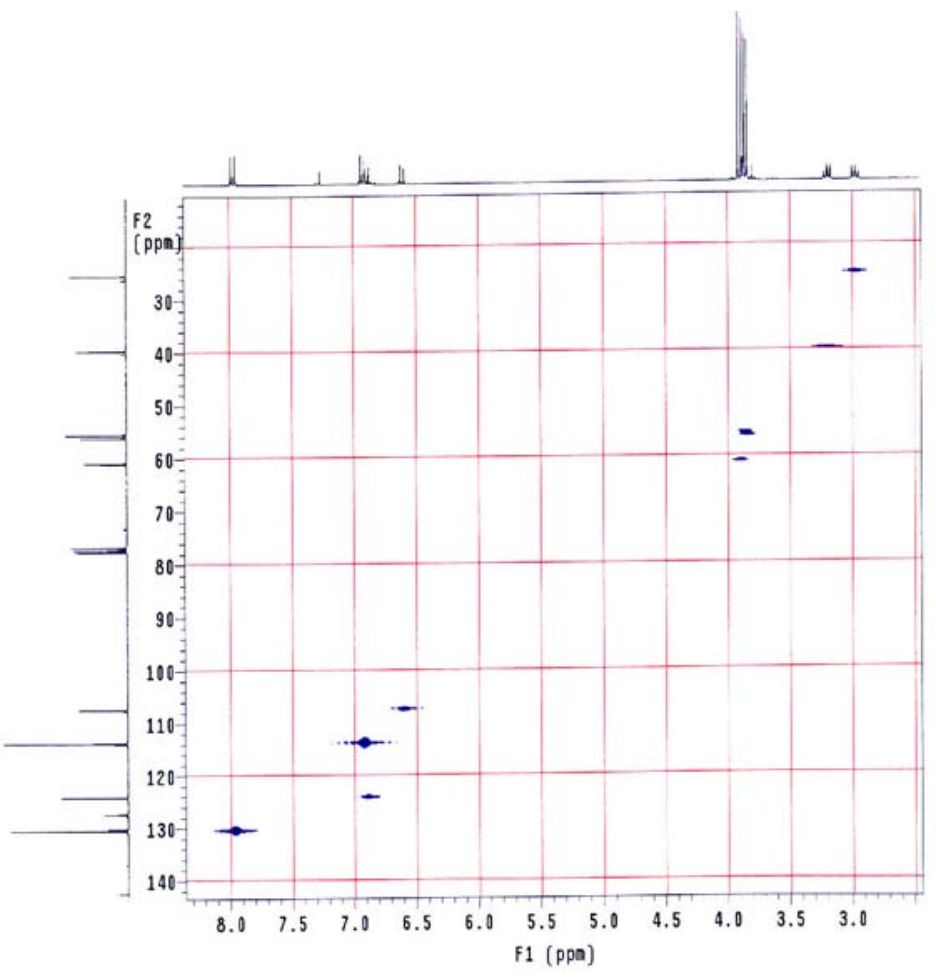

Figure S14. HETCOR spectrum ( $75 \mathrm{MHz}, \mathrm{CDCl}_{3}$ ) of compound 6.

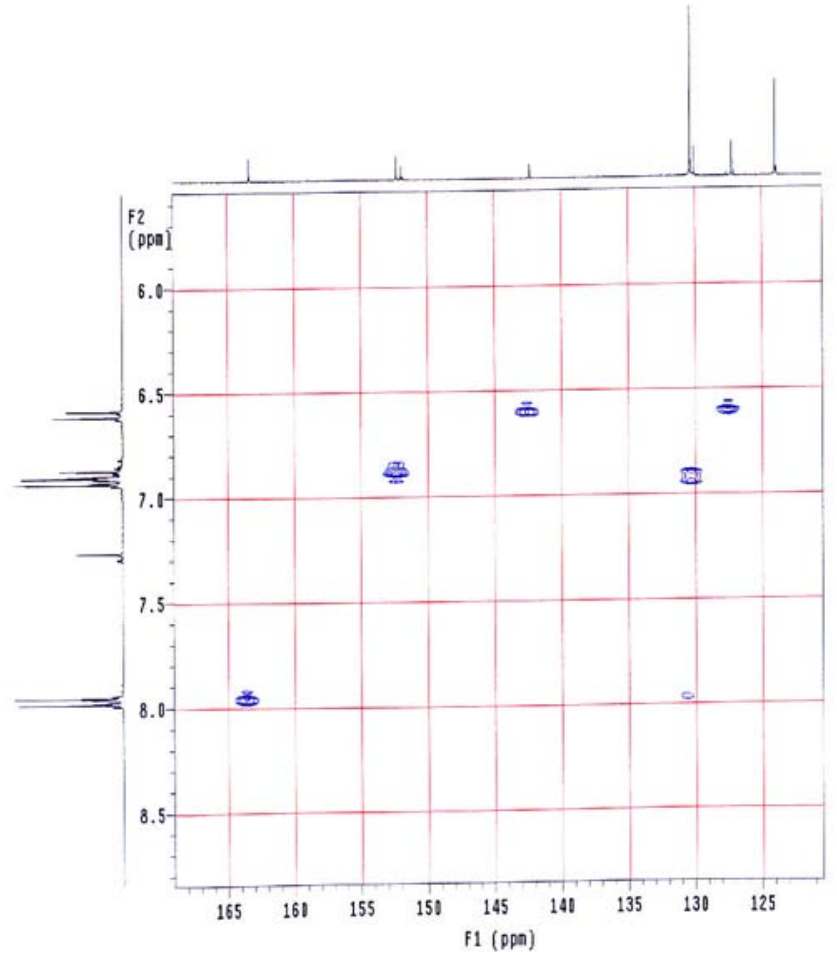

Figure S15. HMBC spectrum of compound 6 (expansion). 


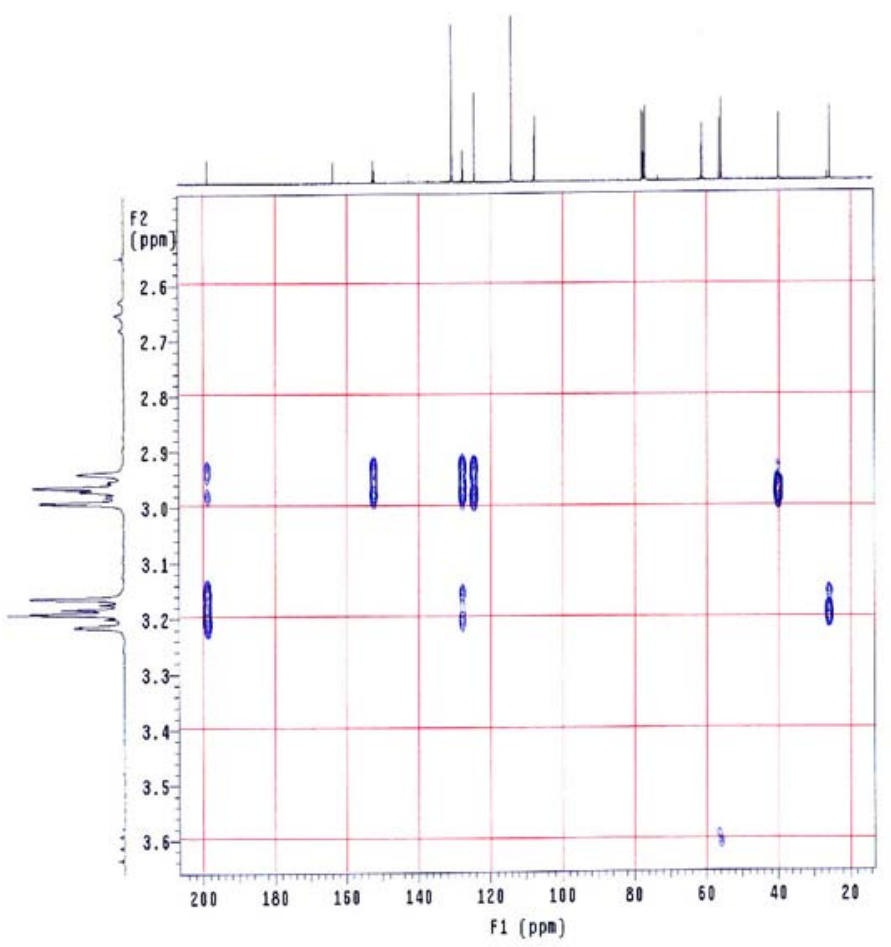

Figure S16. HMBC spectrum of compound 6 (expansion).

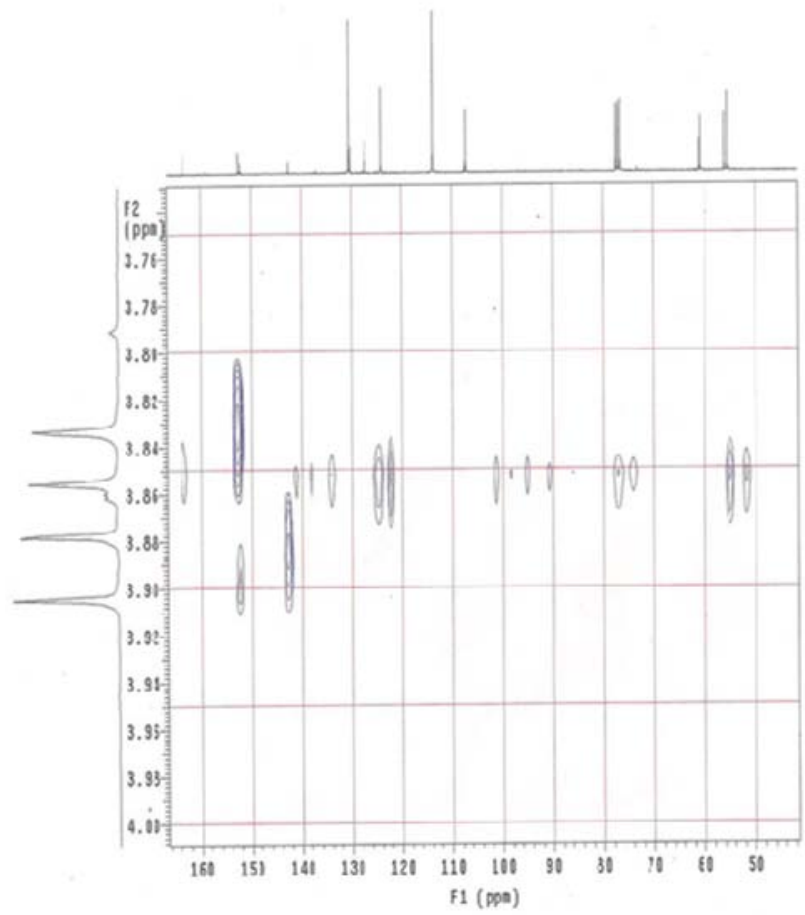

Figure S17. HMBC spectrum of compound 6 (expansion). 


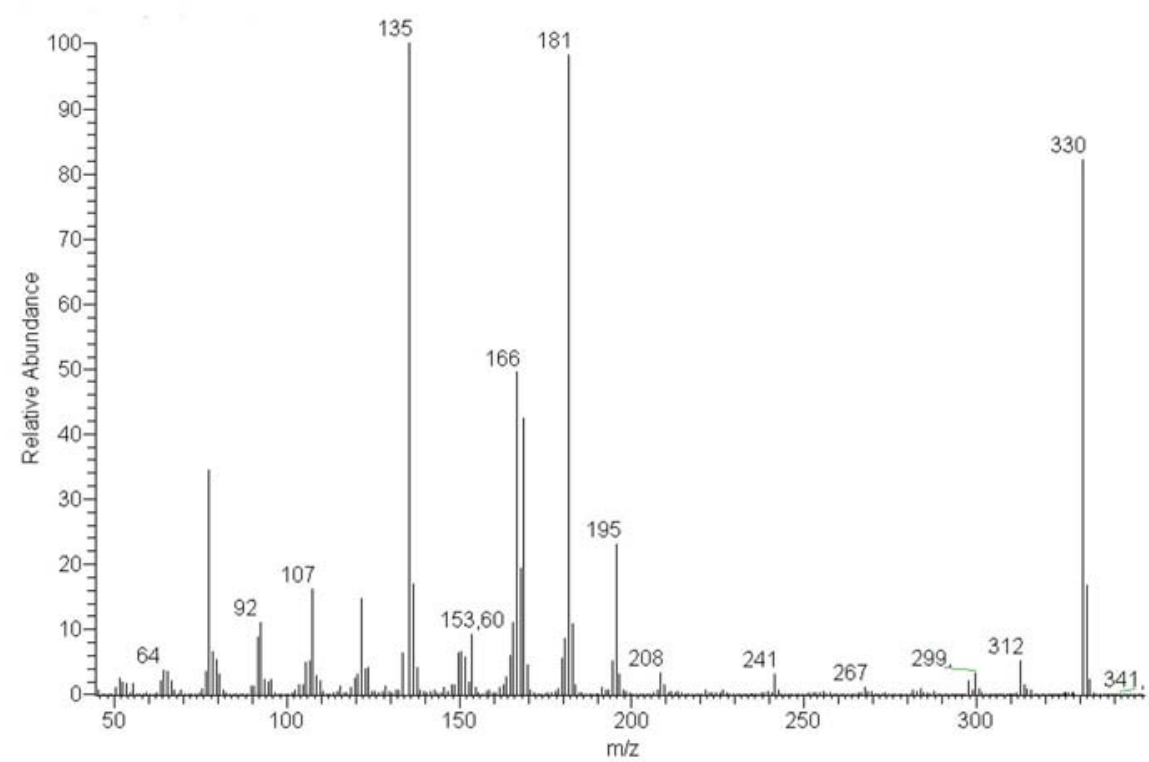

Figure S18. Mass spectrum of compound 6 (CG-MS).

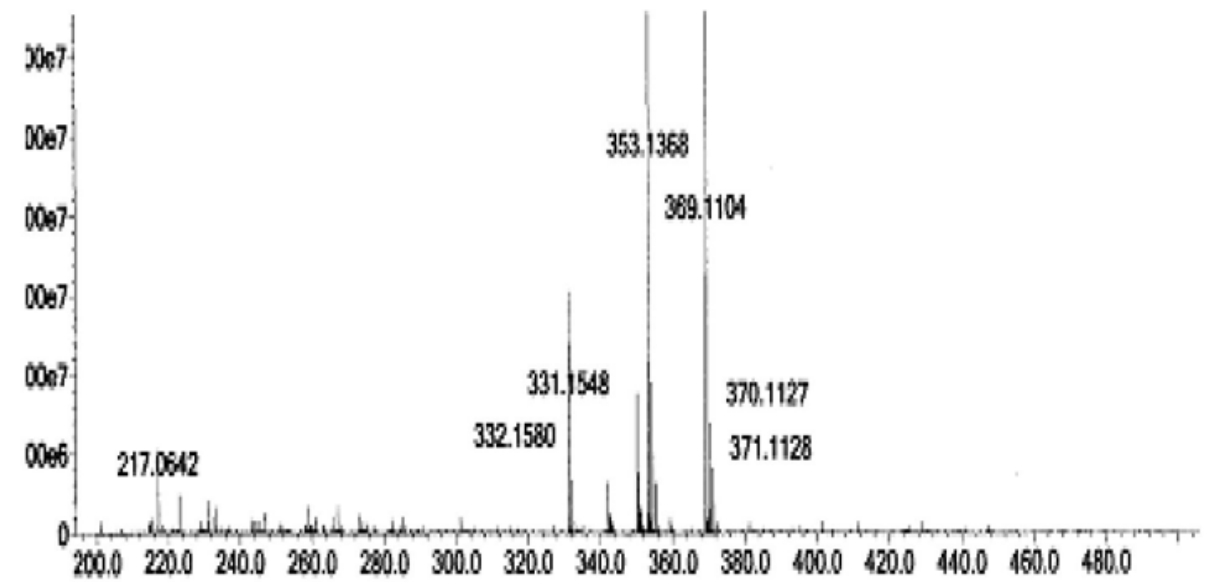

Figure S19. High resolution mass spectrum of compound 6. 